\title{
Peran KH. Idham Chalid dalam Konferensi Islam Asia Afrika di Kota Bandung Tahun 1965
}

\author{
Andri Nurjaman, Asep Sulaeman \\ Fakultas Adab dan Humaniora \\ Universitas Islam Negeri Sunan Gunung Djati Bandung \\ Email: andrienurjaman99@gmail.com
}

\begin{abstract}
This article discusses the history and the role of KH Idham Chalid in organizing the AsianAfrican Islamic Conference in Bandung in 1965. The conference was held on 6-14 March 1965 in the city of Bandung precisely in Gedung Merdeka aimed at combating $\neg$ neocolonialism and uniting the solidarity of Muslims of Asian and African nations. According to Sukarno, the conference was that every country in Asia and Africa could be free from all forms of colonialism and therefore the religion of Islam could flourish in every country. This Islamic Conference deals with how to contribute to the the greatness of Islam, to get complete independence and to organize solidarity. KH Idham Chalid became the central figure of the Asia Africa Islamic Conference. The method used in this study is the historical research method, while the steps of the research are as follows: First heuristic second critique third interpretation and fourth historiography. From this study, we have seen that KH Idham Chalid had given huge contribution to organize this important Islamic Conference and also could manage the potential conflict and debate among the delegation of Muslim countries.
\end{abstract}

Keywords: Islamic Conference, Muslim Figure, Indonesian Islam, Asia-African Islam 
Peran KH. Idham Chalid dalam Konferensi Islam Asia Afrika di Kota Bandung Tahun 1965| Andri Nurjaman dan Asep Sulaiman

\section{Pendahuluan}

Kota Bandung disebut dengan ibu kota Asia Afrika setelah dilaksanakanya Konferensi berbasis internasional yaitu Konferensi Asia Afrika pada tahun 1955. Konferensi ini telah berhasil menyatukan bangsa Asia dan Afrika untuk keluar dari belenggu kolonialisme dan imperialisme menuju kemerdekaan dan perdamaian dunia melalui semangat Bandung. 10 tahun setelah itu, diselenggarakan kembali Konferensi berbasis internasional, namun pada tahun 1965 Konferensi ini khusus untuk menyatukan ide dan solidaritas kalangan umat Islam bangsa Asia dan Afrika untuk melawan neokolonialisme yaitu dalam konferensi Islam Asia Afrika, konferensi ini diharapkan menjadi mercu suar api Islam khususnya bagi umat Islam di kawasan Asia dan Afrika dan umumnya bagi umat Islam di dunia. ${ }^{1}$

Konferensi Islam Asia Afrika tersebut adalah kelanjutan perjuangan dari Konferensi Asia Afrika yang dilandasi oleh spirit keIslaman yang berada di dada setiap jiwa umat Islam Asia Afrika untuk melawan sistem kejahatan internasional yang bernama neo-kolonialisme. Neo-kolonialisme ini telah campur tangan di dunia Islam dengan berkedokan kerjasama di bidang politik, ekonomi, kebudayaan dan bahkan agama. Padahal sistem tersebut adalah sebuah penjajahan bentuk baru. Kota Bandunglah yang menjadi saksi perjuangan dua konferensi tersebut untuk kemajuan bangsa Asia dan Afrika dari cengkraman kolonialisme dan imperialisme baik bentuk lama maupun dalam bentuk baru.

Menurut pandangan Roeslan Abdulgani dalam bukunya yang berjudul The Bandung Connection menuturkan bahwa Bandung menampakan diri sebagai kota penghubung, pusat koneksi atau center of connection dari negara-negara dan rakyat-rakyat Asia Afrika dalam menyusun barisan kesetiakawanan. Bandung pada waktu itu tidak hanya sebagai center of ceonnection between goverments antar pemerintah namun juga sebagai pusat penghubung antar pejuang-pejuang Asia-Afrika. ${ }^{2}$

Dari kota Bandung bangsa Asia dan Afrika melalui dua konferensi tersebut telah membangunan dan memperkuat barisan kesetiakawanan untuk memperjuangkan kemerdekaan dan perdamaian serta bercita-cita

${ }^{1}$ S. Hidajat dkk, Bandung Guide Book, (Bandung: The Executive Committee Of The Africa Asia Islamic Conference I, 1965), 8.

2 Roeslan Abdulgani, The Bandung Connection Konperensi Asia-Afrika di Bandung tahun 1955, (Bandung: MKAA-Dirjen Diplik Kemenlu RI, 2015), Cetakan keempat, 12. 
menciptakan dunia baru yang bebas dari segala macam tindakan penjajahan, diskriminasi dan rasisme.

Konferensi Islam Asia Afrika diselenggarakan pada 6 sampai 14 Maret 1965. Melalui Konferensi Islam Asia Afrika ini bangsa Asia dan Afrika yang mayoritas Muslim berupaya untuk menyatukan ide dan gerak perjuangan untuk melawan dan menentang neo-imperialisme atau imperialisme corak baru, bahkan bisa dikatakan melalui Konferensi Islam ini merupakan puncak untuk merealisasikan Dasa Sila Bandung yang lahir dari Konferensi Asia Afrika. Dasa Sila Bandung tersebut mengandung tiga nilai utama yaitu kerjasama internasional, kesetaraan dan hidup berdampingan secara damai.

Menurut Kamus Besar Bahasa Indonesia, konferensi adalah rapat atau pertemuan untuk berunding atau bertukar pendapat mengenai suatu masalah yang dihadapi bersama. Konferensi juga diartikan sebagai media komunikasi tatap muka yang memberikan suatu kemungkinan bahwa dengan konferensi tersebut bisa mencapai suatu pemahaman bersama yang tidak mungkin dicapai melalui komunikasi secara tertulis. ${ }^{3}$

Konferensi dalam Islam juga bisa diartikan sebagai musyawarah untuk menyelesaikan suatu persoalan yang dihadapi bersama. Sikap bermusyawarah ini adalah ajaran Islam yang terdapat dalam Alquran dan telah di contohkan oleh Nabi Muhammad SAW beserta sahabatnya yang selalu bermusyawarah untuk mencari solusi dari persoalan yang sedang dihadapi. Adapun ayat Alquran yang memerintahkan untuk bermusyawarah tersebut ada dalam QS Asy-syura ayat 38 yang berbunyi :

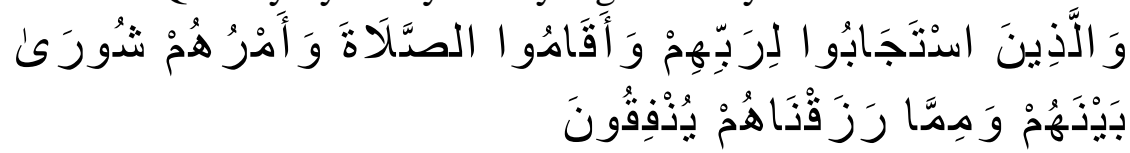

Artinya: "bagi orang-orang yang menerima (mematuhi) seruan Tuhannya dan mendirikan shalat, sedangkan urusan mereka (diputuskan) dengan musyawarah diantara mereka, dan mereka yang menafkahkan sebagian dari rezeki yang Kami berikan kepada kamu".

Sedangkan dalam hadis nabi yang diriwayatkan al-Baihaqi dari Ibnu Abbas, Rasululla SAW bersabda yang artinya: "Allah dan Rasul-Nya tidak memerlukan musyawarah dengan siapapun, akan tetapi disuruhnya musyawarah itu adalah semata-mata untuk kebaikan umatku"

${ }^{3}$ KBBI Online, arti kata konferensi, Diambil dari https://kbbi.web.id/konferensi pada pukul 17.1229 Januari 2020. 
Konferensi Islam Afrika Asia yang diadakan di Bandung tepatnya di Gedung Merdeka pada tahun 1965 ini bertujuan untuk menyatukan semangat umat Islam di Asia dan Afrika untuk berjuang melenyapkan penjajahan bentuk baru, dan untuk mencari solusi bagi permasalahan yang sedang dihadapai oleh umat Islam di Asia dan Afrika dalam meningkatkan kesejahteraan umat Islam dan kerjasama antar negara-negara Islam Asia Afrika.

Konferensi Islam Asia Afrika bertujuan menyatukan ide dan semangat perjuangan Muslimin Asia dan Afrika untuk bersama melawan neo-imperialisme yang telah menekan dan menindas. Umat Islam bangsa Asia dan Afrika harus bersatu, menggalang solidaritas untuk melawan imperialisme model baru supaya Islam bisa makmur dan mekar.

Berkumpulnya negara-negara Asia dan Afrika dalam konferensi Islam Asia Afrika ini tidak hanya menyatukan solidaritas politik tapi karena sesuai dengan Pancasila khususnya sila pertama yaitu kepercayaan kepada Tuhan yang maha kuasa, yaitu Allah SWT yang mayoritas bangsa Asia dan Afrika adalah beragama Islam.

Neo-kolonialisme dan neo-imperialisme adalah suatu komplotan internasional yang bekerja sama untuk menindas bangsa-bangsa di Asia dan Afrika, maka Konferensi Islam Asia Afrika adalah upaya untuk bekerjasama melawan segala bentuk baru kolonialisme dan imperialisme tersebut pada tingkat internasional. Karena menurut Presiden Soekarno kolonialisme dan imperialisme itu belum mati, tapi sekarat. Artinya ada bentuk penjajahan baru yang berbeda dengan penjajahan lama dan ini yang disebut dengan neokolonialisme. Neo-kolonialisme tersebut telah menjajah umat Islam bangsa Asia dan Afrika dari segi politik, ekonomi, militer dan kebudayaan. Penjajahan bentuk baru ini lebih berbahaya dari pada kolonialisme klasik. ${ }^{4}$

Konferensi Asia Afrika pada tahun 1955 bertujuan untuk melawan kolonialisme dan terbukti setelah KAA banyak negara-negara di Asia dan Afrika yang merdeka. Namun penjajah barat tidak kehabisan akal untuk menjajah kembali bekas jajahannya, mereka menggunakan cara baru untuk menjajah dengan sistem ketergantungan negara-negara kecil atau negaranegara berkembang atau Negara-negara bekas jajahan kepada negara

${ }^{4}$ Dokumen, Teks Pidato Ketua Organizing Committee, J.M. K.H, D.R Idham Chalid pada Opening Ceremony KIAA Hari Sabtu Tanggal 6 Maret 1965, (Bandung: Africa-Asia Islamic Conference, 1965), 4-5. 
penjajah yang memiliki kekuatan. Sistem tersebut merupakan sistem penjajahan bentuk baru yang disebut neo-kolonialisme. Konferensi Islam Asia Afrika pada tahun 1965 bertujuan untuk menghadapi dan melawan neokolonialisme tersebut.

Indonesia sebagai penduduk umat Islam terbesar didunia dan sebagai bangsa Asia yang dijajah oleh kaum imperialis harus menyatukan ide, hati, perjuangan dan solidaritas untuk melawan penjajahan tersebut, karena solidaritas inilah adalah inti dari ajaran yang dibawa oleh Rasulullah SAW. Potensi umat Islam di negara Asia dan Afrika merupakan suatu kekuatan yang sangat besar dan ampuh untuk melawan segala bentuk imperalisme. ${ }^{5}$

Para delegasi dari setiap negara yang hadir pada Konferensi Islam Asia Afrika berperinsipkan persatuan umat Islam di bawah bendera agama yang sama demi menciptakan dunia yang baru yaitu dunia yang penuh dengan kemerdekaan, keadilan dan perdamaian di atas muka bumi milik Allah SWT. ${ }^{6}$

Terselenggaranya Konferensi Islam Asia Afrika ini tidak bisa dipisahkan dari peran seorang ketua pelaksananya yaitu K.H. Dr. Idham Chalid, beliau dengan Nahdlatul Ulama dan ormas Islam Indonesia lainnya seperti Muhammadiyyah, Al-wasliyyah, Gasbiindo, PSII, Perti bahkan pusrah AD menyatukan ide, hati dan perjuangan mengenai persatuan Islam yang bulat, dimana setiap perorangan atau kelompok merongrong atau menjajah terhadap segolongan atau sebagian umat Islam, maka dianggap sebagai perongrong atau penajajah umat Islam secara keseluruhan. Ini adalah ajaran Islam yang dibawa oleh Rasulullah SAW, bahwa semua kaum muslimin ibarat satu tubuh, jika pada salah satu tubuh ada yang sakit maka semua tubuh yang lain akan merasakan sakit pula.

Kepemimpinan seorang Idham Chalid tidak bisa diragukan lagi, karena ketika beliau menjadi ketua penyelenggara konferensi Islam Asia Afrika di kota Bandung tahun 1965 beliau sedang menjabat sebagai ketua umum PBNU pada tahun ke Sembilan. ${ }^{7}$ Ide gagasan tentang penyatuan solidaritas

\footnotetext{
${ }^{5}$ Yadi Suryadi, Peran Indonesia dalam Konperensi Islam Asia Afrika (6-14 Maret 1965), SKRIPSI, (Bandung: Departemen Pendidikan dan Kebudayaan Universitas Negri Padjadjaran Fakultas Sastra, 1984), 8-9.

${ }^{6}$ Dokumen, Teks Pidato Ketua Organizing Committee, J.M. K.H, D.R Idham Chalid pada Opening Ceremony KIAA Hari Sabtu Tanggal 6 Maret 1965, (Bandung: Africa-Asia Islamic Conference, 1965), 9-10.

7 Nur Hidayatullah, Idham Chalid di Nahdlatul Ulama, (Semarang: UIN Walisango, 2018), Jurnal Idrak Vol, 1 No, 1, Desember 2018.
} 
umat Islam bangsa Asia dan Afrika ini tidak terlepas dari peran Idham Chalid, oleh karena itu beliau berhasil membawa NU berkiprah pada konferensi Islam Asia Afrika. Selanjutnya Idham Chalid akan menjadi presiden organisasi kerjasama Islam Asia Afrika dikancah internasional.

Melalui semangat Bandung dari Konferensi Asia Afrika pada tahun 1955 banyak negara yang merdeka dari imperialisme dan sejak saat itu pula kota Bandung menjadi ibu kota Asia Afrika, namun belum banyak orang yang mengetahui tentang konferensi Islam Asia Afrika pada tahun 1965, 10 tahun setelah konferensi Asia Afrika diselenggarakan kembali konferensi berbasis internasional, di tempat dan kota yang sama dengan bernuansa dan bernafaskan Islam dibawah bendera ukhuwah Islamiyyah untuk mencapai tujuan yang sama.

Tujuan utama dari diadakannya konferensi Islam Asia Afrika adalah untuk melawan neo-imperialisme yang tidak kalah berbahayanya dengan imperialisme bentuk lama. Oleh karena itu harus ada penyatuan ide dan kekuatan kolektif untuk melawan neo-imperialisme tersebut.

\section{Metode Penelitian}

Metode yang digunakan dalam penelitian ini adalah metode kualitatif. Dengan metode ini penulis melakukan pencarian data dan fakta secara nyata dan apa adanya. Adapun tahap-tahap metode sejarah dalam penelitian ini di antaranya yaitu terdiri dari tahap heuristik, tahap kritik, tahap interpretasi dan tahap historiografi.

Sumber-sumber sejarah yang dibutuhkan dalam penulisan penelitian ini dikumpulkan berdasarkan bahan-bahan yang ada relevansi dengan tema yang penulis pilih. Heuristik merupakan suatu keterampilan dalam menemukan, menangani, dan memperinci atau mengklasifikasikan catatancatatan. Pada tahapan ini, kegiatan diarahkan pada penjajakan, pencarian dan pengumpulan sumber-sumber yang akan diteliti, baik yang terdapat di lokasi penelitian, temuan benda maupun sumber lisan. ${ }^{8}$

Dalam proses penyusunan penelitian ini, penulis menghimpun sumbersumber yang berkenaan dengan KH Idham Chalid dan Konferensi Islam Asia Afrika. Diantaranya, buku yang berjudul Bandung Guide Book, The Bandung Connection, arsip-arsip berupa teks pidato Presiden Soekarno di KIAA, teks pidato KH Idham Chalid di KIAA, dokumen terakhir deklarasi KIAA,

\footnotetext{
${ }^{8}$ Sulasman, Metode Penelitian Sejarah, (Bandung: Pustaka Setia, 2014), 93.
} 
dokumen deklarasi OIAA, dokumen pernyataan komite nasional OIAA, dokumen deklarasi kongres pertama OIAA, majalah api Islam Haluan Politik Negara no satu sampai sembilan dan buku yang berjudul Islam dan demokrasi terpimpin karya KH Idham Chalid. Sumber benda berupa fotofoto KIAA dan foto-foto KH Idham Chalid di KIAA. Adapun sumber lainnya yaitu skripsi karya Yadi Suryadi Wiryasaputra yang berjudul Peranan Indonesia dalam KIAA, skripsi karya Pudjiastuti Sudewo yang berjudul KIAA I, skripsi karya Atifatur Rohmah dengan judul Dinamika Sejarah Politik NU: Studi Tentang Hubungan NU dan Negara pada masa Dr. KH. Idham Chalid tahun 1956-1984 M, jurnal karya Nur Hidayatullah dengan judul Idham Chalid di NU, buku karya Ahmad Muhajir dengan judul Idham Chalid Guru Politik Orang NU, dan buku karya Arief Mudatsir Mandan dengan judul Tilas Pengabdian Idham Chalid Tanggung Jawab Politik NU dalam Sejarah.

Kritik sumber adalah suatu usaha menganalisa, memisahkan dan mencari suatu sumber untuk memperoleh keabsahan sumber yang dibutuhkan. Dalam hal ini, dilakukan penyeleksian apakah data tersebut akurat atau tidak, baik dari segi bentuk maupun isinya sehingga dapat dipertanggungjawabkan. ${ }^{9}$

Setelah melakukan tahap pertama yaitu tahap pengumpulan data-data lewat tahapan heuristik, tahapan selanjutnya yaitu kritik. Tahapan ini merupakan tahap mengkritisi sumber yang sudah didapatkan. Dalam tahapan ini yang dilakukan adalah menentukan kredibitas dan otensitas sebuah sumber baik itu naskah atau dokumen yang nantinya akan ditentukan tingkat validitasnya dilihat dari teks dan nilai-nilai isi. Tahapan kritik ini dibagi menjadi dua yaitu kritik ekstern dan intern.

Interpretasi adalah penafsiran data atau disebut juga analisis sejarah, yaitu penggabungan atas sejumlah fakta yang telah diperoleh. ${ }^{10}$ Pada tahap ini atau disebut dengan interpretasi, bisa dilakukan dengan dua cara, yaitu sintesis dan analisis. Interpretasi sering disebut biangnya subjektivitas karena dalam proses ini masuk pemikiran-pemikiran penulis atau suatu fakta sejarah. Fakta-fakta tersebut kemudian dirangkai menjadi suatu rentetan tak terputus dari suatu peristiwa. Dalam penulisan sejarah subjektifitas itu

${ }^{9}$ Dudung Abdurahman, Metode Penelitian Sejarah, (Jakarta: PT. Logos Wacana Ilmu, 1999), . 11. 107.

${ }^{10}$ Sulasman, Metodologi Penelitian Sejarah, (Bandung : Pustaka Setia, 2014), 
diakui, namun subjektifitas itu tetap harus dihindari. Dalam interpretasi ini, penulis berusaha untuk bersikap netral tanpa memihak siapapun. Karena penelitian yang peneliti lakukan, didasarkan pada metode-metode yang bersifat objektif, dan hasil yang diharapkan dari penelitian ini, dapat mengetahui bagaimana peran KH Idham Chalid dalam Konferensi Islam Asia Afrika di kota Bandung tahun 1965. Dalam pengkajian masalah yang terdapat dalam penelitian ini penulis menggunakan teori The Great Man yang dikemukakan oleh Thomas Charyle, yakni The History of the world is butthe biography of great men. Bahwa sejarah diciptakan dari biografibiografi orang besar dari sumber yang penulis peroleh, dapat dikatakan bahwa peran KH Idham Chalid selaku ketua panitia Konferensi Islam Asia Afrika yang telah memperjuangkan konferensi tersebut untuk menggalang solidaritas bersama umat Islam di Asia dan Afrika dalam rangka menghadapi neo-kolonialisme.

Historiografi adalah proses penyusunan fakta sejarah dan berbagai sumber yang telah diseleksi dalam bentuk penulisan sejarah. Setelah melakukan tahapan heuristik yaitu pencarian data, kemudian setelah itu melakukan tahapan kritik, peneliti pun mulai mengkritik data yang telah di dapatkan, lalu tahapan interpretasi yaitu penafsiran, setelah menafsirkan adalah tahapan akhir yaitu historiografi, yaitu tahapan penulisan sejarah

\section{Hasil dan Pembahasan}

\section{Sejarah Konferensi Islam Asia Afrika}

\section{Neo-imperialisme}

Neo-kolonialisme ini memperlihatkan suatu kerjasama, namun dibalik itu kaum nekolim memiliki tujuan untuk menciptakan suatu sistem ketergantungan negara bekas jajahan terhadap bekas penjajahnya. Sistem ketergantungan diberbagai bidang kepada negara lain adalah sistem baru dari penjajahan dan hal ini yang dihadapi oleh umat Islam bangsa Asia dan Afrika saat itu.

Maka untuk menghadapi penjajahan baru seperti diatas haruslah menyatukan ide dan perjuangan secara kolektif bagi kaum Muslimin khususnya di Asia dan Afrika, dalam Islam diajarkan bahwa umat Islam itu bagaikan satu tubuh, jika ada bagian tubuh yang sakit maka bagian tubuh yang lain akan merasakan sakit. Konferensi Islam Asia Afrika dilandaskan oleh semangat Bandung dan ada dalam naungan ukhuwah Islamiyyah untuk 
merajut kembali solidaritas umat Islam yang merupakan inti dari ajaran yang dibawa oleh Rasulullah SAW untuk menghapuskan segala macam tindakan kedzoliman yang dilakukan oleh kaum imperialis diatas muka bumi milik Allah SWT dan ini sesuai dengan UUD 1945.

\section{Muncul nya ide Konferensi Islam}

Bangsa Asia dan Afrika yang dijajah sekian laman oleh kaum kolonialis dan imperialis telah bangkit pada abad ke-20, dan umat Islamlah yang paling merasakan sakit akibat kedzoliman penjajahan tersebut. Kaum penjajah sudah memperkirakan bahwa umat Islam adalah mayoritas yang ada di benua Asia dan Afrika maka ini menjadi pusat kekhawatiran penjajah, oleh karena itu dengan segala cara kaum penjajah ingin menghancurkan Islam untuk memperlambat pergerakan Islam tersebut. Namun ternyata dalam catatan sejarah pergerakan nasional Indonesia umat Islamlah garda paling depan dalam mengusir penjajah melalui santri dan kiai. ${ }^{11}$

Umat Islam telah menunjukan peranannya dalam mengusir penjajah, oleh karena itu umat Islam Indonesia menyadari bahwa harus ada kerjasama untuk menyatukan perjuangan bersama umat Islam di Asia dan Afrika untuk terbebas dari segala bentuk penindasan di berbagai bidang, sehingga Islam bisa subur dan mekar di Asia dan Afrika. Neo-kolonialisme adalah bentuk penjajahan baru yang dilakukan oleh kaum imperialis dengan mendirikan negara-negara boneka yang secara politik telah merdeka, namun secara ekonomi, budaya dan spiritual masih dijajah. Melalui Konferensi Islam Asia Afrika kaum Muslimin ingin memberikan jawaban atas persoalan tersebut.

\section{Konferensi Pendahuluan di Jakarta tahun 1964}

Daftar Acara Konferensi Pendahuluan

\begin{tabular}{|l|l|l|l|}
\hline NO & \multicolumn{1}{|c|}{ WAKTU } & \multicolumn{1}{c|}{ AGENDA } & \multicolumn{1}{c|}{ TEMPAT } \\
\hline 1. & $\begin{array}{l}\text { Sabtu, 6 Juni 1964 } \\
10.00-13.00 \text { WIB }\end{array}$ & Upacara Pembukaan & $\begin{array}{l}\text { Markas Besar } \\
\text { Ganefo Senayan } \\
\text { Jakarta }\end{array}$ \\
\hline 2. & $\begin{array}{l}\text { Minggu, 7 Juni } \\
1964\end{array}$ & $\begin{array}{l}\text { Meninjau Riung } \\
\text { Gunung Puncak Jawa }\end{array}$ & $\begin{array}{l}\text { Riung Gunung } \\
\text { Puncak Jawa Barat }\end{array}$ \\
\hline
\end{tabular}

11 Yadi Suryadi Wiryasaputra, Peran Indonesia dalam Konperensi Islam Asia Afrika (6-14 Maret 1965), (Bandung: Departemen Pendidikan dan Kebudayaan Universitas Negri Padjadjaran Fakultas Sastra, 1984), 20-21. 
Peran KH. Idham Chalid dalam Konferensi Islam Asia Afrika di Kota Bandung Tahun 1965| Andri Nurjaman dan Asep Sulaiman

\begin{tabular}{|c|c|c|c|}
\hline & $08.30 \mathrm{WIB}$ & Barat & \\
\hline \multirow[t]{2}{*}{3.} & $\begin{array}{l}\text { Senin, } 8 \text { Juni } 1964 \\
09.00 \text { WIB }\end{array}$ & $\begin{array}{l}\text { Meninjau gedung } \\
\text { DPRGR, Masjid Istiqlal, } \\
\text { Gedung Pola, DEPAG } \\
\text { RI, IAIN Ciputat }\end{array}$ & $\begin{array}{l}\text { gedung DPRGR, } \\
\text { Masjid Istiqlal, } \\
\text { Gedung Pola, } \\
\text { DEPAG RI, IAIN } \\
\text { Ciputat }\end{array}$ \\
\hline & $19.30 \mathrm{WIB}$ & $\begin{array}{l}\text { Pembicara tidak resmi } \\
\text { para ketua delegasi }\end{array}$ & Hotel Indonesia \\
\hline 4. & $\begin{array}{l}\text { Selasa, } 9 \text { Juni } 1964 \\
09.00 \text { WIB }\end{array}$ & $\begin{array}{l}\text { Sidang Paripurna } \\
\text { Tertutup Pertama }\end{array}$ & $\begin{array}{l}\text { Markas Besar } \\
\text { Ganefo Senayan } \\
\text { Jakarta }\end{array}$ \\
\hline \multirow[t]{4}{*}{5.} & $\begin{array}{l}\text { Rabu, 10 Juni } 1964 \\
\text { 09.00-12.00 WIB }\end{array}$ & $\begin{array}{l}\text { Sidang Paripurna } \\
\text { Tertutup Kedua }\end{array}$ & $\begin{array}{l}\text { Markas Besar } \\
\text { Ganefo Senayan } \\
\text { Jakarta }\end{array}$ \\
\hline & 16.30-17.30 WIB & $\begin{array}{l}\text { Ramah Tamah dengan } \\
\text { menteri perhubungan } \\
\text { alim ulama (KH Fatah } \\
\text { Jassin) }\end{array}$ & $\begin{array}{l}\text { Bali Room Hotel } \\
\text { Indonesia }\end{array}$ \\
\hline & 19.00-21.30 WIB & Pawai Obor & $\begin{array}{l}\text { Bermuara ke Markas } \\
\text { Besar Ganefo }\end{array}$ \\
\hline & $21.30 \mathrm{WIB}$ & $\begin{array}{l}\text { Sidang Paripurna } \\
\text { Tertutup Ketiga }\end{array}$ & $\begin{array}{l}\text { Markas Besar } \\
\text { Ganefo Senayan } \\
\text { Jakarta }\end{array}$ \\
\hline \multirow[t]{3}{*}{6.} & $\begin{array}{l}\text { Kamis, 11 Juni } \\
1964 \\
09.00 \text { WIB }\end{array}$ & $\begin{array}{l}\text { Sidang Komisi Tertutup } \\
\text { Pertama }\end{array}$ & $\begin{array}{l}\text { Markas Besar } \\
\text { Ganefo Senayan } \\
\text { Jakarta }\end{array}$ \\
\hline & 16.30-17.30 WIB & $\begin{array}{l}\text { Ramah Tamah oleh } \\
\text { Wakil Perdana Menteri } \\
\text { III (Dr. Chairul Saleh) }\end{array}$ & $\begin{array}{l}\text { Rumah Dr. Chairul } \\
\text { Saleh di Jln Tengku } \\
\text { Umar No. } 9 \text { Jakarta }\end{array}$ \\
\hline & $20.00 \mathrm{WIB}$ & $\begin{array}{l}\text { Sidang Komisi Tertutup } \\
\text { Kedua }\end{array}$ & $\begin{array}{l}\text { Markas Besar } \\
\text { Ganefo Senayan } \\
\text { Jakarta }\end{array}$ \\
\hline \multirow[t]{2}{*}{7.} & $\begin{array}{l}\text { Jumat, } 12 \text { Juni } 1964 \\
09.00 \text { WIB }\end{array}$ & $\begin{array}{l}\text { Sidang Komisi Tertutup } \\
\text { Ketiga }\end{array}$ & $\begin{array}{l}\text { Markas Besar } \\
\text { Ganefo Senayan } \\
\text { Jakarta }\end{array}$ \\
\hline & 16.30-18.00 WIB & Penghormatan wanita & \\
\hline
\end{tabular}




\begin{tabular}{|c|c|c|c|}
\hline & & $\begin{array}{l}\text { Indonesia kepada } \\
\text { delegasi wanita dari } \\
\text { Thailand (Ny. Sang } \\
\text { Daoo Siawalla) }\end{array}$ & \\
\hline & $20.00 \mathrm{WIB}$ & $\begin{array}{l}\text { Resepsi oleh ketua } \\
\text { kehormatan panitia } \\
\text { nasional KIAA (Jendral } \\
\text { A.H Nasution) }\end{array}$ & $\begin{array}{l}\text { Kartika Bahari } \\
\text { Tanjung Priok }\end{array}$ \\
\hline 8. & $\begin{array}{l}\text { Sabtu, 13 Juni } 1964 \\
09.00 \text { WIB }\end{array}$ & $\begin{array}{l}\text { Sidang Paripurna } \\
\text { Tertutup Keempat }\end{array}$ & $\begin{array}{l}\text { Markas Besar } \\
\text { Ganefo Senayan } \\
\text { Jakarta }\end{array}$ \\
\hline & 16.30-18.00 WIB & $\begin{array}{l}\text { Ramah Tamah dengan } \\
\text { Presiden Soekarno }\end{array}$ & $\begin{array}{l}\text { Istana Merdeka } \\
\text { Jakarta }\end{array}$ \\
\hline & $20.00 \mathrm{WIB}$ & $\begin{array}{l}\text { Jamuan oleh delegasi } \\
\text { Indonesia }\end{array}$ & \\
\hline 9. & $\begin{array}{l}\text { Minggu, 14 Juni } \\
1964 \\
09.00 \mathrm{WIB}\end{array}$ & $\begin{array}{l}\text { Penutupan Konferensi } \\
\text { Pendahuluan }\end{array}$ & $\begin{array}{l}\text { Stadion Utama } \\
\text { Gelora Bung Karno }\end{array}$ \\
\hline
\end{tabular}

Pelaksanaan Konferensi Islam Asia Afrika di Bandung tahun 1965 Agenda kegiatan sidang KIAA

\begin{tabular}{|c|c|c|c|}
\hline $\begin{array}{c}\text { SIDANG } \\
\text { KE }\end{array}$ & WAKTU & AGENDA & TEMPAT \\
\hline & $\begin{array}{l}\text { Sabtu, } 6 \text { Maret } 1965 \\
10.30 \text { WIB }\end{array}$ & $\begin{array}{l}\text { Ceremoni Pembukaan } \\
\text { KIAA } \\
\text { (Lagu Indonesia Raya, } \\
\text { Pembacaan Alquran, } \\
\text { Laporan ketua panitia } \\
\text { penyelenggara yaitu } \\
\text { KH Idham Chalid dan } \\
\text { pidato Presiden } \\
\text { Soekarno dan Presiden } \\
\text { Pakistan Ayub Khan }\end{array}$ & $\begin{array}{l}\text { Ruang sidang } \\
\text { Gedung Merdeka }\end{array}$ \\
\hline & $\begin{array}{l}\text { Sabtu, } 6 \text { Maret } 1965 \\
16.00 \text { WIB }\end{array}$ & $\begin{array}{l}\text { Menyaksikan Pawai } \\
\text { Akbar }\end{array}$ & $\begin{array}{l}\text { Depan Gedung } \\
\text { Merdeka }\end{array}$ \\
\hline & $\begin{array}{l}\text { Sabtu, } 6 \text { Maret } 1965 \\
19.00 \text { WIB }\end{array}$ & $\begin{array}{lll}\text { Resepsi } & \text { oleh } & \text { Menteri } \\
\text { Luar } & \text { Negeri } & \text { Dr. }\end{array}$ & $\begin{array}{l}\text { Hotel Savoy } \\
\text { Homan }\end{array}$ \\
\hline
\end{tabular}


Peran KH. Idham Chalid dalam Konferensi Islam Asia Afrika di Kota Bandung Tahun 1965| Andri Nurjaman dan Asep Sulaiman

\begin{tabular}{|c|c|c|c|}
\hline & & Subandrio & \\
\hline \multirow{3}{*}{1} & $\begin{array}{l}\text { Minggu, } 7 \text { Maret } \\
1965 \\
09.00-12.00 \mathrm{WIB} \\
\text { (Sesi Pagi) }\end{array}$ & $\begin{array}{l}\text { Mendengarkan } \\
\text { pandangan dari delapan } \\
\text { delegasi (India, Irak, } \\
\text { Yordania, Kenya, } \\
\text { Kuwait, Jepang, } \\
\text { Lebanon \& Liberia) }\end{array}$ & \multirow[t]{2}{*}{$\begin{array}{l}\text { Ruang sidang } \\
\text { Gedung Merdeka }\end{array}$} \\
\hline & $\begin{array}{l}\text { Minggu, } 7 \text { Maret } \\
1965 \\
15.00 \mathrm{WIB} \\
\text { (Sesi Sore) }\end{array}$ & $\begin{array}{l}\text { Mendengarkan ide-ide } \\
\text { dari } 3 \text { delegasi yaitu } \\
\text { Aljazair, Kamboja \& } \\
\text { Dahomey }\end{array}$ & \\
\hline & $\begin{array}{l}\text { Minggu, } 7 \text { Maret } \\
1965 \\
19.00 \text { WIB }\end{array}$ & $\begin{array}{l}\text { Jamuan Makan Malam } \\
\text { sebagai penutup sidang } \\
\text { pertama }\end{array}$ & $\begin{array}{l}\text { Hotel Savoy } \\
\text { Homan }\end{array}$ \\
\hline \multirow{2}{*}{2} & $\begin{array}{l}\text { Senin, 8 Maret } 1965 \\
09.00 \text { - } 12.00 \mathrm{WIB} \\
\text { (Sesi Pagi) }\end{array}$ & $\begin{array}{l}\text { Mendengarkan } 6 \\
\text { delegasi yaitu RRC, } \\
\text { Maladewa, Maroko, } \\
\text { Nigeria, Kalimantan } \\
\text { Utara \& Pakistan }\end{array}$ & $\begin{array}{l}\text { Ruang sidang } \\
\text { Gedung Merdeka }\end{array}$ \\
\hline & $\begin{array}{l}\text { 15.00 WIB } \\
\text { (Sesi Sore) }\end{array}$ & $\begin{array}{l}\text { Mendengarkan } 5 \\
\text { delegasi yaitu Togo, } \\
\text { Senegal, Sudan, } \\
\text { Suriah, Arab \& } \\
\text { Palestina }\end{array}$ & $\begin{array}{l}\text { Ruang sidang } \\
\text { Gedung Merdeka }\end{array}$ \\
\hline 3 & $\begin{array}{l}\text { Selasa, 9 Maret } \\
1965\end{array}$ & $\begin{array}{l}\text { Mendengarkan usulan } \\
\text { dari Sri Langka }\end{array}$ & $\begin{array}{l}\text { Ruang sidang } \\
\text { Gedung Merdeka }\end{array}$ \\
\hline 4 & $\begin{array}{l}\text { Rabu, } 10 \text { Maret } \\
1965\end{array}$ & Sidang Komisi & $\begin{array}{l}\text { Ruang sidang } \\
\text { Gedung Merdeka }\end{array}$ \\
\hline 5 & $\begin{array}{l}\text { Kamis, } 11 \text { Maret } \\
1965\end{array}$ & $\begin{array}{l}\text { Melanjutkan Sidang } \\
\text { Komisi }\end{array}$ & $\begin{array}{l}\text { Ruang sidang } \\
\text { Gedung Merdeka }\end{array}$ \\
\hline \multirow[t]{2}{*}{6} & $\begin{array}{l}\text { Jum'at, } 12 \text { Maret } \\
1965 \text { sampai pukul } \\
11.45 \text { WIB (Tutup) }\end{array}$ & $\begin{array}{l}\text { Melanjutkan Sidang } \\
\text { Komisi }\end{array}$ & $\begin{array}{l}\text { Ruang sidang } \\
\text { Gedung Merdeka }\end{array}$ \\
\hline & $\begin{array}{l}\text { Sabtu, 13 Maret } \\
1965 \\
09.00 \text { WIB }\end{array}$ & $\begin{array}{l}\text { Sidang Paripurna untuk } \\
\text { mengesahkan hasil } \\
\text { sidang komisi dan }\end{array}$ & $\begin{array}{l}\text { Ruang sidang } \\
\text { Gedung Merdeka }\end{array}$ \\
\hline
\end{tabular}


Peran KH. Idham Chalid dalam Konferensi Islam Asia Afrika di Kota Bandung Tahun 1965| Andri Nurjaman dan Asep Sulaiman

\begin{tabular}{|c|c|c|}
\hline & pentupan sidang KIAA & \\
\hline $\begin{array}{l}\text { Sabtu, } 13 \text { Maret } \\
1965 \\
19.00 \text { WIB }\end{array}$ & $\begin{array}{l}\text { Ramah Tamah dengan } \\
\text { Presiden Soekarno }\end{array}$ & Istana Bogor \\
\hline $\begin{array}{l}\text { Minggu, 14 Maret } \\
1965 \\
07.00 \text { WIB }\end{array}$ & Penutupan KIAA & $\begin{array}{l}\text { Stadion Utama } \\
\text { Gelora Bung } \\
\text { Karno }\end{array}$ \\
\hline
\end{tabular}

\section{Hasil KIAA 1965}

1. Kerjasama menghadapi imperialisme yang berusaha mempertahankan penjajahan atau usaha menciptakan nekolim dengan segala manifestasinya.

2. Memberikan sumbangan positif untuk tercapainya perdamaian dunia.

3. Memperjuangkan hak asasi umat Islam dalam melaksanakan ajaran agama Islam di negara non-muslim.

4. Membangun tata ekonomi baru berlandaskan Islam guna membebaskan diri dari ketergantungan ekonomi terhadap negara imperialis.

5. Memperbaiki tingkat hidup buruh dan tani Islam.

6. Membentuk lembaga riset sosial, ekonomi dan kebudayaan Islam.

7. Untuk meningkatkan kerjasama dan kesatuan perjuangan Islam perlu dibentuk Organisasi Islam Asia Afrika (OIAA).

8. Meningkatkan peranan wanita Islam dalam mensukseskan perjuangan Islam.

9. Meningkatkan kerjasama dalam perjuangan menghadapi invansi Israel terhadap negara Palestina.

10. Mendukung sepenuhnya perjuangan bangsa-bangsa dalam menentukan nasib negara dan bangsanya sendiri. ${ }^{12}$

\section{Peran KH Idham Chalid dalam Konferensi Islam Asia Afrika di Kota Bandung tahun 1965 Sekilas biografi KH Idham Chalid}

${ }^{12}$ Yadi Suryadi Wiryasaputra, Peran Indonesia dalam Konperensi Islam Asia Afrika (6-14 Maret 1965), (Bandung: Departemen Pendidikan dan Kebudayaan Universitas Negri Padjadjaran Fakultas Sastra, 1984), 83-84. 
KH Idham Chalid lahir pada hari Senin 27 Agustus 1922 di Setui Kalimantan Selatan dari pasangan suami istri Muhammad Chalid dan Umi Hani. Beliau menyelesaikan pendidikan dasarnya di Madrasah Islam di Pekapuran dan melanjutkan sekolah menengah dan atas di Pondok Modern Gontor. Idham pernah belajar untuk mendalami bahasa Jepang di Jakarta. Pengalaman organisasi beliau mulai ditempuh usai pulang dari Gontor dan menjadi kepala sekolah di Madrasah Rasyidiyyah dan mendirikan Itti'hadul Ma'had Islamiyyah (IMI). Idham Chalid juga pernah menjadi anggota Persatuan Rakyat Indonesia (PRI) pada tahun 1945, Serikat Muslimin Indonesia (Sermi), Sentral Organisasi Pemberontak Indonesia Kalimantan (SOPIK) tahun 1947, dicalonkan oleh Badan Koordinasi partai-partai Republiken (SKI, Sermi dan Gappika) sebagai anggota dewan daerah Banjar pada tahun 1949, anggota DPR RIS mewakili PB Sermi, anggota parlemen sementara daerah Banjar pada tahun 1950. Karir politik Idham Chalid dimulai dari aktif di NU diantaranya di Ansor, PB Ma'arif NU, majelis pertimbangan politik PBNU setelah NU memisahkan diri dari Masyumi. Idham Chalid pernah menjadi sekretaris jendral PBNU pada tahun 1952, menjadi ketua lajnah pemilihan umum NU danterpilih sebagai anggota DPR dari fraksi NU pada tahun 1955. Sedangkan pada tahun $1956 \mathrm{KH}$ Idham Chalid terpilih sebagai ketua umum PBNU. Pada masa demokrasi terpimpin Idham pernah mejabat sebagai Wakil Perdana Menteri, anggota Dewan Pertimbangan Agung Sementara (DPAS), wakil ketua MPRS. Sedangkan pada masa orde baru KH Idham Chalid pernah menjabat sebagai Menteri Kesejahteraan Rakyat, ketua PPP, ketua MPR dan DPR RI sampai tahun 1977 dan pada tahun 1978 KH Idham Chalid terpilih sebagai Dewan Pertimbangan Agung (DPA). Setelah lengser dari jabatan ketua umum di PBNU, KH Idham Chalid selanjutnya menjadi Mustasyar PBNU dan menjadi Rois 'Am JATMAN. KH Idham Chalid juga mempunyai lembaga pendidikan Darul Ma'arif di Jakarta Selatan dan lembaga pendidikan Darul Qur'an di Cisarua Bogor. Pada tahun 2010 KH Idham Chalid meninggal pada usia 88 tahun karena sakit yang dideritanya selama 10 tahun terakhir. Pemikiran politik KH Idham Chalid yang menarik adalah menerima demokrasi terpimpinnya Presiden Soekarno melalui konsep syuro.

\section{Peran KH Idham Chalid sebagai Panitia Nasional dan Organizing Committee}


Panitia Nasional ini selanjutnya mengadakan pertemuan di Markas Besar Ganefo Senayan Jakarta pada 22 Mei 1964 yang menghasilkan daftar acara untuk konferensi pendahuluan, tata tertib konferensi pendahulan dan susunan delegasi Indonesia untuk konferensi pendahuluan juga telah memutuskan anggota delegasi Indonesia, penasehat dan panitia pekerja Indonesia untuk Konferensi Islam Asia Afrika. ${ }^{13}$

Disini KH Idham Chalid terpilih sebagai ketua yang merangkap sebagai anggota untuk konferensi pendahuluan di Jakarta pada tahun 1964. Konferensi pendahuluan ini membahas persiapan untuk pelaksanaan Konferensi Islam Asia Afrika di Kota Bandung pada tahun 1965.

Sebagai panitia Nasional KIAA, KH Idham Chalid pada upacara ceremonial pembukaan Konferensi Pendahuluan di Markas Besar Ganefo Senayan Jakarta beliau menyampaikan pidato pembukaanya yang berisi mengenai inisiatif Indonesia untuk menyelenggarakan Konferensi Islam Asia Afrika sebagai bentuk rasa tanggung jawab kepada agama Islam dan sebagai bentuk solidaritas umat Islam bangsa Asia dan Afrika untuk melawan segala macam penjajahan demi terciptanya dunia yang penuh kedamaian.

Selanjutnya pada sidang paripurna tertutup pertama konferensi pendahuluan, KH Idham Chalid mengesahkan tata tertib dan daftar acara konferensi pendahuluan, sidang ini juga telah membentuk susunan panitia konferensi pendahuluan dan $\mathrm{KH}$ Idham Chalid terpilih sebagai ketua konferensi pendahuluan tersebut. Oleh karena itu karena KH Idham Chalid terpilih sebagai ketua konferensi pendahuluan, maka ketua delegasi Indonesia untuk konferensi pendahuluan dipegang oleh $\mathrm{H}$. Anwar Tjokroaminoto. $^{14}$

Sedangkan pada sidang paripurna tertutup kedua tepatnya pada 10 Juni 1964 yang dipimpin oleh KH Idham Chalid membicarakan pandangan umum dari semua delegasi yang hadir di konferensi pendahuluan tersebut. Dan pada sidang paripurna tertutup ketiga telah disetujui bahwa KIAA akan dimulai pada tanggal 6 sampai 14 Maret 1965 bertempat di gedung Merdeka Kota Bandung, adapun biaya ditanggung secara gotong royong. Pada sidang paripurna tertutup ketiga ini juga telah membentuk panitia penyelenggara

${ }^{13}$ Dokumen, Konferensi Islam Asia Afrika (Laporan Konferensi Pendahuluan) tanggal 6-14 Juni 1964, (Jakarta: Biro Penerangan Panitia Nasional KIAA, 1964), 61.

${ }^{14}$ Pudjiastuti Sudewo, Konferensi Islam Asia Afrika I, (Depok: Fakultas Sastra Universitas Indonesia, 1989), 28. 
(Organizing Comitte), panita pelaksana (executive committee) dan wakilwakil dari penitia pelaksana.

Selanjutnya pada sidang paripurna tertutup terakhir memutuskan bahwa KH Idham Chalid sebagai ketua Organizing Committee atau panitia penyelenggara. Adapun wakil ketuanya yaitu Al-haj Y.K YAkub dari Nigeria, sekretaris jendral yaitu KH Ahmad Syaichu dari Indonesia, wakil sekretaris jendral yaitu Pahawan Disamamba dari Philiphina dan anggotanya dari Irak dan Thailand. Sedangkan executive committee diserahkan kepada Indonesia. ${ }^{15}$

KH Idham Chalid sebagai organizing committee dan Indonesia sebagai tuan rumah Konferensi Islam Asia Afrika telah mempersiapkan segala hal untuk mensuskeskan konferensi Islam tersebut. Oleh karena itu kepanitian dibagi menjadi dua, yaitu ada panitia lokal dan komite organisasi serta komite pelaksana. Panitia lokal jawa barat untuk KIAA terdiri dari pelindung yaitu Wali Kota Bandung, Ketua DPRD dan kepala KUA. Panitia juga telah mempersiapkan 23 dokter, penerjemah bahasa Arab, Inggris, Perancis dan Tionghoa, hadir wartawan sebanyak 120 baik lokal maupun luar negeri.

KH Idham Chalid sebagai ketua komite ogenisasi KIAA pada tanggal 28 Februari 1965 telah mendengarkan laporan dari setiap biro-biro dalam tugasnya masing-masing untuk mempersiapkan KIAA, dan pada umumnya semua biro menyatakan sudah siap dengan rencananya sesuai dengan arahan.

a. Peran KH Idham Chalid sebagai Pimpinan Sidang

Pada hari Minggu tanggal 7 Maret 1965 pukul 09.00 WIB sidang pertama Konferensi Islam Asia Afrika dimulai dan KH Idham Chalid terpilih secara aklamasi sebagai pimpinan sidang KIAA tersebut, KH Ahmad Syaich sekkretaris jendral sidang dan 4 orang sebagai wakil ketua yaitu $\mathrm{KH}$ Dr Huballah dari Rakyat Persatuan Arab, Al-haj Y.K Jakub dari Nigeria, Prof Hamid Ahmad Khan dari Pakistan dan Syekh Abdul Aziz dari Saudi Arabia. ${ }^{16}$ Tugas KH Idham Chalid sebagai ketua sidang adalah mengatur jalannya sidang dari awal sampai akhir. Pada umumnya selama persidangan berjalan dengan lancar.

${ }^{15}$ Antara, Minggu 14 Juni 1964, No. 165/A-3, 1.

${ }^{16}$ Yadi Suryadi Wiryasaputra, Peran Indonesia dalam Konferensi Islam Asia Afrika (6-14 Maret 1965), (Bandung: Departemen Pendidikan dan Kebudayaan Universitas Negeri Padjadjaran Fakultas Sastra, 1984), 64. 
Namun ada sebuah peristiwa yang menonjol dalam persidangan di Konferensi Islam Asia Afrika, yaitu tepatnya pada sidang paripurna kedua yang diselenggarakan pada hari Senin 8 Maret 1965. Pada sidang kedua ini terjadi pertentangan pendapat antara delegasi dari Pakistan dan delegasi dari India mengenai status Kashmir. Hamid Ahmad Khan delegasi dari Pakistan menggunakan kesempatan pada sidang kedua didalam Konferensi Islam Asia Afrika untuk dijadikan arena memperjaungkan kepentingan politiknya mengenai Kashmir yang dikuasai oleh India. Beliau menceritakan kepada sidang kondisi kaum Muslimin di daerah Kashmir tersebut.

Delegasi dari Pakistan tersebut menyinggung Kashmir dan mengutuk masalah pengusiran serta pembunuhan kaum Muslimin yang merupakan golongan minoritas di India. Dan hal ini menjadikan delegasi dari India terus meminta interupsi dan protes berulang kali. Sehingga suasana sidang menjadi panas. ${ }^{17}$

Namun pernyataan Hamid Ahamd Khan delegasi dari Pakistan tersebut dibantah oleh delegasi dari India yang anggota delegasinya ada yang datang dari Kashmir menyatakan bahwa:

"Janganlah kita membicarakan soal politik dan pertentangan antar kedua Negara, hindarilah pertentangan itu dan marilah kita bicarakan persatuan umat Islam di seluruh dunia. Hal ini akan membawa waktu kalau kita membicarakan soal politik mengenai kasmir ini, maka lebih baik kita membicarakan secara saudara dengan saudara". 18

Delegasi India yang berasal dari Kasmir tersebut menceritakan pula mengenai kedudukan kaum Muslimin di daerah Kashmir. Dan pada dasarnya delegasi India yang dari Kasmir itu keberatan dengan pernyataan dari delegasi Pakistan dan memintanya agar soal Kashmir tidak di bawa dan diperdebatkan dalam Konferensi Islam Asia Afrika ini.

Dengan kelihaian dan kecakapan kepemimpinan $\mathrm{KH}$ idham Chalid dalam mengatur lalu lintas sidang, perdebatan kedua delegasi ini bisa diselesaikan dengan baik. KH Idham Chalid dan KH Ahmad Syaikhu bisa

${ }^{17}$ Solichin Salam, KIAA Fadjar Kebangkitan Umat Islam, Majalah Api Islam No. 1 Thn. 1 Juli 1965. 29.

${ }^{18}$ Dokumen, Varia Konferensi Islam Asia Afrika, (Jakarta: Koleksi Arsip Nasional Republik Indonesia, 1965), 10. 
menghindarkan benturan kepentingan dalam jalannya Konferensi Islam tersebut.

Tidak hanya itu, keadaan bisa diatas karena semangat dan jiwa ukhuwah Islamiyyah yang ada didalam jiwa kedua negara tersebut yaitu India dan Pakistan. Masih ada kesadaran diantara kedua delegasi tersebut bahwa sesama kaum Muslim adalah saudara.Terlihat bahwa delegasi dari Pakistan dan India membawa kepentingan rakyat Kashmir kedalam Konfensi, tetapi berkat kemampuan pengendalian suasana sidang berhasil melahirkan suatu keputusan yang memuaskan kedua belah pihak. ${ }^{19}$ Dan akhirnya ketika selesai dari sidang paripurna kedua, delegasi dari Pakistan menghampiri delegasi dari India dan keduanya saling berpelukan dan kemudian dikerumuni oleh delegasi-delegasi dari negara Asia Afrika lainnya. ${ }^{20}$

Negara-negara Asia dan Afrika lainnya mengharapkan India dan Pakistan damai dan bersatu, karena sama-sama saudara seagama dan setanah air. Kejadian ini mengandung pelajaran yang dalam bagi umat Islam di Indonesia dan Asia Afrika bahwa kaum penjajah telah meninggalkan duri dalam daging bangsa Asia dan Afrika. Kaum Nekolim selama ini telah berusaha dengan sekuat tenaga untuk mengadu domba antara kita seagama dan sebangsa. ${ }^{21}$

Pertentangan antara India dan Pakistan ini merupakan yang kedua kalinya, karena pada Konferensi Asia Afrika tahun 1955 juga terjadi pertentangan antara kedua delegasi tersebut yang juga terkait masalah Kasmir. Namun penulis tidak akan banyak membahas mengenai sengketa Kasmir pada Konferensi Asia Afrika tersebut.

Perbedaan yang ada di dunia Islam sengaja di besar-besarkan dan dipertajam oleh penjajah atau oleh kaum nekolim supaya umat Islam tidak bersatu dan bercerai berai dan akhirnya kekuatan Islam akan lemah. Hal ini bertujuan untuk kepentingan politik kolonialnya. Dan disini terlihat bahwa kekuatan umat Islam ada dalam persatuan.

19 Yadi Suryadi Wiryasaputra, Peran Indonesia dalam Konperensi Islam Asia Afrika (6-14 Maret 1965), (Bandung: Departemen Pendidikan dan Kebudayaan Universitas Negri Padjadjaran Fakultas Sastra, 1984), 91-92.

${ }^{20}$ Yadi Suryadi Wiryasaputra, Peran Indonesia dalam Konperensi Islam Asia Afrika (6-14 Maret 1965), (Bandung: Departemen Pendidikan dan Kebudayaan Universitas Negri Padjadjaran Fakultas Sastra, 1984), 69.

${ }^{21}$ Solichin Salam, KIAA Fadjar Kebangkitan Umat Islam, Majalah Api Islam No. 1 Thn. 1 Juli 1965. 29. 
Politik divide et impera atau politik adu domba adalah senjata kaum nekolim untuk mempertahankan politik kolonialnya. Negara-negara di Asia dan Afrika telah nyata sebagai korban dari politik nekolim tersebut. Contohnya India dan Pakistan yang terus berseteru merupakan bukti nyata dari sistem politik adu domba tersebut.

Pada sidang paripurna ketiga KH Idham Chalid sebagai ketua sidang KIAA dan Prof Hamid Ahmad Khan sebagai wakil ketua sidang telah memutuskan untuk menerima usulan dari semua delegasi mengenai Presiden Soekarno yang akan dinobatkan sebagai Champion of Islam and Freedom. ${ }^{22}$

Dan satu hal lagi, Indonesia melalui peran ketua KIAA yaitu $\mathrm{KH}$ Idham Chalid tidak memasukan Negara Malaysia sebagai proyek nekolim secara tersendiri atau dalam agenda khusus Konferensi Islam Asia Afrika, melainkan Indonesia tetap berusaha untuk melahirkan suatu sikap bersama mengenai konsepsi menghadapi imperialisme dalam segala bentuknya. ${ }^{23}$

Pernyataan mengenai sikap anti imperalisme disetujui dalam Konferensi Islam ini, sehingga masalah konfrontasi Indonesia-Malaysia secara tidak langsung atau politis diplomatis mendapat dukungan dari seluruh negara yang hadir dalam KIAA. Hal ini terbukti dan bisa dilihat dalam jalannya sidang-sidang paripurna KIAA tidak ada negara peserta yang mengusulkan masalah konfrontasi Indonesia-Malaysia untuk dibicarakan dalam Konferensi Islam tersebut. Oleh sebab itu, Indonesia melalui $\mathrm{KH}$ Idham Chalid sangat bijak dalam menentukan sikap seperti ini yang tidak menjadikan KIAA sebagai media untuk mendapat dukungan politik dari negara yang hadir.

Dengan demikian Konferensi Islam Asia Afrika mempunyai tujuan dan makna yang tinggi, KIAA sebagai tangga untuk menyatukan perjuangan umat Islam Asia Afrika baik di tingkat regional maupun pada tingkat internasional. ${ }^{24}$ Konferensi Islam Asia Afrika telah berhasil memberikan tumpuan dasar pemikiran kerjasama antara Islam dalam memperjuangkan kehidupan dunia yang penuh kedamaian untuk terlepas dari segala bentuk

${ }^{22}$ Dokumen, Dari Bandung Pembentukan Dunia Baru Ditingkatkan, (Jakarta: Departemen Agama Koleksi Yayasan Idayu, 1965), 12.

${ }^{23}$ Yadi Suryadi Wiryasaputra, Peran Indonesia dalam Konperensi Islam Asia Afrika (6-14 Maret 1965), (Bandung: Departemen Pendidikan dan Kebudayaan Universitas Negri Padjadjaran Fakultas Sastra, 1984), 92.

${ }^{24}$ Yadi Suryadi Wiryasaputra, Peran Indonesia dalam Konperensi Islam Asia Afrika (6-14 Maret 1965), (Bandung: Departemen Pendidikan dan Kebudayaan Universitas Negri Padjadjaran Fakultas Sastra, 1984), 92-93. 
penjajahan baik corak lama (kolonialisme dan imperialisme) ataupun corak baru (neo-kolonialisme).

Hasil-hasil dari KIAA mengenai dasar-dasar persatuan dan kerjasama antara umat Islam Asia Afrika yang dijiwai oleh semangat api Islam dan ini merupakan wujud nyata dari ukhuwah Islamiyyah. Maka jelaslah target dan tujuan umat Islam Asia dan Afrika yang salah satunya untuk persatuan dan bekerjasama pada bidang agama, politik, ekonomi, kebudayaan, maupun pada bidang ilmiah, wanita, kepemudaan, dan sosial. ${ }^{25}$

Peran KH Idham Chalid dalam Konferensi Islam Asia Afrika telah menggambarkan sosok Idham Chalid sebagai pemimpin yang cakap, politikus yang lihai dan cerdas serta ulama yang ramah dan baik. Adapun ide-ide KH Idham Chalid yang tergambar dalam pidatonya menunjukkan bahwa beliau sangat tahu betul kondisi umat Islam pada saat ini dan solusi yang harus ditempuh oleh umat Islam tersebut.

\section{b. Pemikiran KH Idham Chalid di KIAA}

Gagasan KH Idham Chalid dalam Konferensi Islam Asia Afrika bisa terlihat dalam pidato beliau ketika pembukaan Konferensi Islam Asia Afrika, menurutnya Konferensi Islam ini adalah suatu rahmat Tuhan karena berkat adanya pertolongan dan karunia dari Allah SWT KIAA ini bisa terlaksanakan di Indonesia. Konferensi Islam ini juga merupakan suatu pertanda semakin kuatnya barisan yang cinta kemerdekaan, perdamaian dan keadilan. ${ }^{26}$ Salah satu dari tujuan KIAA adalah membangun solidaritas atau persatuan dalam umat Islam dunia khususnya bangsa Asia dan Afrika, dan terbukti dengan KIAA hadir 37 negara dari Asia Afrika untuk bersama-sama duduk membicarakan hal-hal untuk kemajuan Islam di negara-negara Asia Afrika tersebut, serta untuk mewujudkan dunia yang penuh dengan kedamaian, keadilan dan terbebas dari segala bentuk penjajahan.

KH Idham Chalid juga menuturkan bahwa KIAA ini merupakan malapetaka bagi orang yang tidak setuju dengan Konferensi Islam ini bagaikan tinju raksasa yang memukul jantung hati mereka. Namun $\mathrm{KH}$ Idham Chalid tidak menyebutkan nama kelompok atau orang-orang yang tidak setuju dengan Konferensi Islam ini. Ditambah lagi ketika penundaan

\footnotetext{
${ }^{25}$ Solichin Salam, KIAA Fadjar Kebangkitan Umat Islam, Majalah Api Islam No. 1 Thn. 1 Juli 1965. 29.

${ }^{26}$ Dokumen, Teks Pidato Ketua Organizing Committee JM KH Dr Idham Chalid pada Opening Ceremony KIAA Hari Sabtu tanggal 6 Maret 1965, (Bandung: Asia-Afrika Islamic Conference, 1965, 1.
} 
terselenggarakannya Konferensi Islam, kelompok yang tidak setuju membuat berita palsu atau dalam bahasa Idham adalah mereka menyusun khayalan yang ganjil, mereka membuat cerita kosong disebarkan untuk memperkuat maksud mereka yang buruk bahwa terjadi kesulitan yang serius didalam penyelenggaraan KIAA. ${ }^{27}$

Adapun alasan penundaan Konferensi Islam Asia Afrika ini karena untuk kesempurnaan peristiwa yang bersejarah ini. Mengingat pada waktu itu Indonesia sedang mengalami cuaca yang kurang baik yaitu hujan lebat yang mengakibatkan jalan raya menjadi terganggu. Oleh sebab itu panitia dibawah perintah presiden Soekarno memperbaiki terlebih dahulu jalan-jalan khususnya didaerah Jawa Barat. ${ }^{28}$ Bagi yang setuju dan mendukung KIAA ini menurut Idham Chalid merupakan jalan diatas garis yang ditunjukan Tuhan, dengan KIAA ini merupakan jalan menuju masa depan yang terang benderang.

Bangsa Asia dan Afrika termasuk Amerika Latin pada masa tersebut sedang menghadapi masalah yaitu masih banyak tindakan kedzoliman, penderiataan baik lahiriyyah maupun batiniyyah yaitu masih adanya imperialisme dan kolonialisme. Oleh karena itu bangsa Asia Afrika harus segera mencari solusi dan penyelesaian mengenai masalah tersebut.

Bangsa Asia dan Afrika menunjukan kehormatannya pada masa perlawanan terhadap penjajah, tidak sedikit yang gugur menjadi syuhada. Dan kita berhasil memukul mundur kaum penjajah tersebut dari negaranegara Asia Afrika. Namun imperialisme dan kolonialisme tersebut belumlah mati, sistem penjajahan baru telah muncul dan telah merayap ke bagian mental atau bagian ruhaniyah yang disebut dengan neo-kolonialisme. Dan masalah inilah yang sedang dihadapi umat Islam bangsa Asia dan Afrika. $^{29}$

${ }^{27}$ Dokumen, Teks Pidato Ketua Organizing Committee JM KH Dr Idham Chalid pada Opening Ceremony KIAA Hari Sabtu tanggal 6 Maret 1965, (Bandung: Asia-Afrika Islamic Conference, 1965, 1.

${ }^{28}$ Dokumen, Teks Pidato Ketua Organizing Committee JM KH Dr Idham Chalid pada Opening Ceremony KIAA Hari Sabtu tanggal 6 Maret 1965, (Bandung: Asia-Afrika Islamic Conference, 1965, 1.

${ }^{29}$ Dokumen, Teks Pidato Ketua Organizing Committee JM KH Dr Idham Chalid pada Opening Ceremony KIAA Hari Sabtu tanggal 6 Maret 1965, (Bandung: Asia-Afrika Islamic Conference, 1965, 3. 
KH Idham Chalid selanjutnya menjelaskan bahwa kolonialisme adalah suatu komplotan internasional yang bersifat internasional. ${ }^{30}$ Oleh karena itu solusi untuk melawannya adalah dengan potensi yang bersifat internasional pula. Oleh sebab itu maka negara-negara di Asia dan Afrika harus bersatu dan menguatkan barisan yang kuat untuk menciptakan kemerdekaan, perdamaian dan keadilan.

Akibat dari kolonialisme dan imperialisme tersebut terjadi kemunduran bagi bangsa Asia dan Afrika. Maka pada masa ini banga Asia dan Afrika harus bersatu dan berjuang kembali untuk menghacurkan sistem penjajahan baru yang lebih berbahayanya dengan sistem penajahan lama untuk semata-mata tercapainya kemerdekaan yang penuh dan keadilan bagi Islam dan bangsa Asia dan Afrika sendiri. ${ }^{31}$

Presiden Soekarno pernah menyampaikan dalam pidatonya di Konferensi Tingkat Tinggi (KTT) Non Blok di Kairo bahwa imperialisme belum mati melainkan sekarat. ${ }^{32}$ Praktek penjajahan belumlah berakhir, selain masih banyaknya negara yang masih dijajah secara nyata. Pada saat bersamaan bangsa Asia dan Afrika sedang menghadapi bentuk penjajahan baru yang disebut neo-kolonialisme yang menyerang di bidang politik, ekonomi, militer dan kebudayaan dengan cara kerjasama supaya negaranegara bekas jajahannya memiliki ketergantungan kepada negara yang lebih besar $^{33}$ dan akan dijadikan pengikut negara besar tersebut.

Neo-kolonialisme ini lebih berbahaya di banding dengan penjajahan lama, dengan kelicikan dan cara baru mereka telah terjadi secara nyata. Umat Islam telah menjadi korban yang nyata melalui penjajahan baru dibidang politik dan ekonomi yang terjadi di beberapa tempat. Oleh karena itu, harus adanya perlawanan yang nyata pula terhadap neo-kolonialisme ini.

${ }^{30}$ Dokumen, Teks Pidato Ketua Organizing Committee JM KH Dr Idham Chalid pada Opening Ceremony KIAA Hari Sabtu tanggal 6 Maret 1965, (Bandung: Asia-Afrika Islamic Conference, 1965, 4.

${ }^{31}$ Dokumen, Teks Pidato Ketua Organizing Committee JM KH Dr Idham Chalid pada Opening Ceremony KIAA Hari Sabtu tanggal 6 Maret 1965, (Bandung: Asia-Afrika Islamic Conference, 1965, 4.

${ }^{32}$ Dokumen, Teks Pidato Ketua Organizing Committee JM KH Dr Idham Chalid pada Opening Ceremony KIAA Hari Sabtu tanggal 6 Maret 1965, (Bandung: Asia-Afrika Islamic Conference, 1965, 4.

${ }^{33}$ Yang dimaksud Negara besar disini adalah kaum imperialis yang menawarkan kerjasama pada Negara-negara jajahannya untuk dijadikan pengikut, inilah sistem penjajahan baru atau neokolonialisme. 
Melalui Konferensi Islam Asia Afrika ini, umat Islam bangsa Asia dan Afrika bermusyawarah untuk membicarakan sumbangan apa yang harus diberikan untuk memperkokoh sendi dan kebesaran Islam yang telah mendapat penderiataan dari bentuk penjajahan baru tersebut. Dan sumbangan apa yang harus diberikan untuk mewujudkan kemerdekaan yang penuh dan untuk memelihara kemerdekaan, keadilan dan kemakmuran bangsa baik yang bersifat lahir maupun batin. Selain itu juga untuk memusyawarahkan rencana yang akan dilakukan di negara Asia dan Afrika yang dilandaskan dengan ajaran Islam untuk melahirkan solidaritas dan kekuatan yang terorganisir. ${ }^{34}$

Umat Islam di Asia dan Afrika merupakan suatu potensi yang besar telah diperkecil peranannya dala kehidupan politik, sosial dan ekonomi melalui neo-kolonialisme tersebut. Islam adalah agama mayoritas di Asia dan Afrika harus bergerak keluar dari sitem penjajahan baru ini, karena dalam ajaran Islam dilarang melakukan tindakan menjajah atau mengekploitasi bangsa kepada bangsa yang lain yang telah menyebabkan kemunduran dan penderitaan, Islam mengajarkan kemerdekaan dan perdamaian.

Konferensi Islam Asia Afrika yang diselenggarakan di Indonesia sebagai penduduk umat Islam terbesar didunia berharap dengan Konferensi Islam ini untuk memperjuangkan umat Islam secara internasional menjalani babak barunya yang lebih militan, lebih terkonsolidasi, dan lebih ampuh serta maju. KIAA ini diselenggarakan di tempat dan kota yang sama yaitu di Kota Bandung lebih tepatnya di Gedung Merdeka yang pada tahun 1955 telah melahirkan Dasa Sila Bandung yang telah meletakan batu pertama dalam perjuangan bangsa Asia dan Afrika, dan selanjutnya pada tahun 1965 secara spresifik umat Islam Asia Afrika kembali bertemu di tempat dan gedung yang sama untuk membangun kembali solidaritas dan melanjutkan perjuangan yang berlandaskan ukhuwah Islamiyyah.

Dengan tegas $\mathrm{KH}$ Idham Chalid dalam pidato pembukaannya di Konferensi Islam Asia Afrika menjelaskan bahwa dalam bidang politik umat Islam dimasing-masing nation atau negaranya harus memberikan sumbangan pikiran berdasarkan ajaran agama dan memainkan partisipasi politik menurut

${ }^{34}$ Dokumen, Teks Pidato Ketua Organizing Committee JM KH Dr Idham Chalid pada Opening Ceremony KIAA Hari Sabtu tanggal 6 Maret 1965, (Bandung: Asia-Afrika Islamic Conference, 1965, 5. 
Peran KH. Idham Chalid dalam Konferensi Islam Asia Afrika di Kota Bandung Tahun 1965| Andri Nurjaman dan Asep Sulaiman

kondisi setempat masing-masing secara maksimal menurut kemampuan yang ada. ${ }^{35}$

Selanjutnya dibidang ekonomi, Idham menyampaikan bahwa bangsa Asia dan Afrika harus memikirkan umat Islam dimasing-masing negara harus memberikan sumbangan pikiran berdasarkan ajaran agama untuk meletakan dasar ekonomi masing-masing negara yang adil dan makmur, yang tidak ada penindasan oleh manusia atas manusia, yang tidak ada perbudakan baik dalam bentuknya yang murni maupun perbudakan yang diselimuti. ${ }^{36}$ Bangsa Asia dan Afrika harus melepaskan sistem ekonomi kapitalisme yang memeras dan terlepas dari keganasan tirani yang mengahambakan diri kepada kebendaan karena ini bertolak belakang dengan ajaran Islam.

Adapun secara kebudayaan, bangsa Asia dan Afrika harus memikirkan umat Islam dimasing-masing negaranya untuk memberikan sumbangan pikiran berdasarkan agama untuk meninggikan nilai ruhani melalui media-media yang terdapat didalam bentuk kebudayaan setempat, perpaduan yang harmoni antara cara dan tujuan sehingga media-media kebudayaan tersebut menjadi kreasi yang hidup. ${ }^{37}$

Idham melanjutkan dalam hubungan internasional antara umat Islam se-Asia dan Afrika untuk memikirkan landasan umum supaya bekerjasama dan saling membantu, baik melalui suatu institusi praktis seperti sekretariat bersama dan untuk memecahkan persoalan bersama dalam rangka kepentingan bersama menurut kebutuhan masing-masing negara yang sedang dihadapi. ${ }^{38}$ Kerjasama internasional antara kaum Muslimin bangsa Asia dan Afrika haruslah diperkuat karena bukan hanya ajaran Islam yang mengharuskan untuk bersatu karena juga dengan saling bekerjasama bisa mewujudkan hal-hal yang dicita-citakan.

${ }^{35}$ Dokumen, Teks Pidato Ketua Organizing Committee JM KH Dr Idham Chalid pada Opening Ceremony KIAA Hari Sabtu tanggal 6 Maret 1965, (Bandung: Asia-Afrika Islamic Conference, 1965, 6.

${ }^{36}$ Dokumen, Teks Pidato Ketua Organizing Committee JM KH Dr Idham Chalid pada Opening Ceremony KIAA Hari Sabtu tanggal 6 Maret 1965, (Bandung: Asia-Afrika Islamic Conference, 1965, 7.

${ }^{37}$ Dokumen, Teks Pidato Ketua Organizing Committee JM KH Dr Idham Chalid pada Opening Ceremony KIAA Hari Sabtu tanggal 6 Maret 1965, (Bandung: Asia-Afrika Islamic Conference, 1965, 7.

${ }^{38}$ Dokumen, Teks Pidato Ketua Organizing Committee JM KH Dr Idham Chalid pada Opening Ceremony KIAA Hari Sabtu tanggal 6 Maret 1965, (Bandung: Asia-Afrika Islamic Conference, 1965, 7. 
Konferensi Islam Asia Afrika ini merupakan tanggung jawab dan tugas bersama yaitu bangsa Asia dan Afrika, bukan hanya sebagai tugas agama melainkan juga tugas sejarah yang ditugaskan kepada generasi pada saat itu untuk generasi masa depan bangsa Asia dan Afrika sendiri. Bangsa Asia dan Afrika harus segera menyusun barisan yang kuat untuk bekerjasama dan saling membantu.

Umat Islam yang datang dari negara-negara Asia dan Afrika berkumpul di Gedung Merdeka pada hakikatnya bersatu dibawah bendera yang sama yaitu bendera agama Islam. Jelasnya Islam sebagai kesatuan, jelas pula kekuatan dan tugas umat Islam Asia Afrika. Selain dari pada itu, di negara masing-masing bangsa Asia dan Afrika harus menjadi umat Islam yang baik dalam beribadah dan berjuang. Secara internasional pun bangsa Asia dan Afrika harus menjadi umat Islam yang baik, bekerjasama untuk menghadapi lawan bersama, teratur dan berprinsip. ${ }^{39}$

\section{Kesimpulan}

Konferensi Islam Asia Afrika yang diselenggarakan di Kota Bandung pada tahun 1965 adalah perjuangan kaum Muslimin bangsa Asia dan Afrika untuk menggalang solidaritas dalam menghadapi neo-kolonialisme. Dalam penelitian ini penulis menghasilkan beberapa kesimpulan yaitu sebagai berikut:

Pertama, Konferensi Islam Asia Afrika dimulai pada hari Sabtu 6 Maret 1965 dibuka resmi oleh Presiden Soekarno dilanjutkan oleh pembacaan ayat suci Al-qur'an dan pidato ketua KIAA yaitu KH Idham Chalid. Dan pada acara sore harinya adalah menyaksikan pawai akbar oleh masyarakat Kota Bandung, sedangkan pada malam harinya diadakan resepsi oleh Menteri Luar Negeri yaitu Dr. Subandrio di Hotel Savoy Homan. Sidang paripurna pertama dilaksanakan pada hari Minggu 7 Maret 1965, sesi pagi mendengarkan dari delapan delegasi sedangkan pada sesi sorenya mendengarkan dari tiga delegasi. Pada malam hari diadakan jamuan makan malam oleh Menteri Agama Syaifuddin Zuhri di Hotel Savoy Homan. Sidang kedua yaitu pada hari Senin 8 Maret 1965 mendengarkan ide-ide dari enam delegasi dan sore harinya lima delegasi. Pada sidang ketiga yang

${ }^{39}$ Dokumen, Teks Pidato Ketua Organizing Committee JM KH Dr Idham Chalid pada Opening Ceremony KIAA Hari Sabtu tanggal 6 Maret 1965, (Bandung: Asia-Afrika Islamic Conference, 1965, 9. 
dilaksnakan pada hari Selasa 9 Maret 1965 mendengarkan usulan dari Sri Langka. Lalu pada hari Rabu 10 Maret 1965 dimulai sidang komisi. Sidang keempat dilaksanakan hari Kamis 11 Maret 1965 yang merupakan sidang komisi. Sedangkan sidang kelima pada hari Jum'at 12 Maret 1965 dilanjutkan sidang komisi tertutup. Dan pada hari Sabtu 13 Maret 1965 pada pagi harinya dilaksanakan sidang paripurna dan pada malam harinya diselenggarakan acara ramah tamah di Istana Bogor oleh Presiden Soekarno. Dan pada hari Minggu 14 Maret 1965 diselenggarakan penutupan KIAA di Stadion Utama Gelora Bung Karno. Hasil dari KIAA adalah 10 butir yang memuat ide-ide perjuangan umat Islam Asia Afrika.

Kedua, peran KH Idham Chalid dalam Konferensi Islam Asia Afrika di Kota Bandung tahun 1965 sebagai ketua panitia nasional dan organizing comiitte KIAA beliau berperan dari Konferensi Pendahuluan dan terpilih sebagai ketua konferensi pendahuluan, KH Idham Chalid memimpin konferensi tersebut untuk mempersiapkan KIAA pada tahun 1965, dan sebagai ketua organizing commiite KH Idham Chalid mempersiapkan segala hal untuk kesuksesan KIAA mulai dari tenaga medis, penerjemah, wartawan sampai kepanitian pun dibagi menjadi dua. Adapun peran KH Idham Chalid sebagai pimpinan sidang Konferensi Islam Asia Afrika melalui kecakapnnya dalam memimpin ketika terjadi perdebatan pada sidang paripurna kedua yaitu antara delegasi Pakistan dan India mengenai Kashmir, KH Idham Chalid bisa mengendalikan suasana sidang yang asalnya panas menjadi dingin kembali dan bisa menghindarkan benturan dari kedua delegasi tersebut dan akhirnya melahirkan suatu keputusan yang memuaskan kedua belah pihak. Tidak hanya itu pada sidang paripurna ketiga KH Idham Chalid telah menerima usul dari semua delegasi mengenai penobatan Presiden Soekarno sebagai Champion of Islam and Freedom. Tidak hanya itu peran KH Idham Chalid dalam sidang KIAA adalah tidak memasukan Malaysia sebagai proyek nekolim secara tersendiri untuk mendapat dukungan dari semua peserta Konferensi mengenai masalah konfrontasi IndonesiaMalaysia. Indonesia tetap berusaha untuk melahirkan suatu sikap bersama dalam menghadapi imperialisme di segala macam bentuk dan manifestasinya. Adapun pemikiran KH Idham Chalid dalam Konferensi Islam Asia Afrika tertuang dalam pidato pembukaannya pada KIAA, didalam pidatonya tersebut tergambar bahwa KH Idham Chalid sangat mengetahui masalah yang sedang dihadapi oleh umat Islam yaitu neo- 
kolonialisme serta bahaya dari sistem penjajahan baru tersebut di berbagai bidang dan solusi yang harus diperbuat oleh umat Islam, KH Idham Chalid menyampaikan melalui ide-idenya mengenai pentingnya solidaritas khususnya bagi umat Islam bangsa Asia dan Afrika. Beliau juga mengutarakan mengenai cita-cita dunia yang penuh kemerdekaan dan perdamaian. Oleh karena itu, melalui KIAA umat Islam harus memusyawarahkan kontribusi untuk menghadapi masalah tersebut baik dalam bidang politik, ekonomi, budaya dan hubungan internasional. 
Peran KH. Idham Chalid dalam Konferensi Islam Asia Afrika di Kota Bandung Tahun 1965| Andri Nurjaman dan Asep Sulaiman

\section{Daftar Sumber}

\section{Arsip}

Dokumen, Beberapa Catatan tentang Konferensi Islam Asia Afrika pertama di Bandung, (Jakarta: Lembaga Sejarah dan Kebudayaan Departemen Pendidikan dan Kebudayaan, 1965).

Dokumen, Dari Bandung Pembentukan Dunia Baru Ditingkatkan, (Jakarta: Departemen Agama Koleksi Yayasan Idayu, 1965).

Dokumen, Deklarasi Konferensi Islam Asia Afrika, (Bandung: KIAA, 1965). Dokumen, Inaugural address of the President of the Republic of Indonesia at the opening ceremony of the African Asian Islamic Conference in Bandung 6 march 1965, (Bandung: Africa-Asia Islamic Conference, 1965).

Dokumen, Inaugural Address of the President Soeharto at Opening of the First Congress of the Afro-Asia Islamic Organisation, (Bandung: OIAA, 1970).

Dokumen, Konferensi Islam Asia Afrika (Laporan Konferensi Pendahuluan) tanggal 6-22 Juni 1964, (Jakarta: Koleksi Yayasan Idayu, 1964).

Dokumen, Monthly Magazine on Indonesian Politics and Culture, (Jakarta: Depatemen of Imformation Republic of Indonesia, 1965).

Dokumen, Pernyataan Komite Nasional OIAA, (Jakarta: OIAA Komite Nasional, 1965).

Dokumen, Teks Pidato Ketua Organizing Committee, J.M. K.H, D.R Idham Chalid pada Opening Ceremony KIAA Hari Sabtu Tanggal 6 Maret 1965, (Bandung: Africa-Asia Islamic Conference, 1965).

Dokumen, Varia Konferensi Islam Asia Afrika, (Jakarta: Koleksi Arsip Nasional Republik Indonesia, 1965).

\section{Buku}

Abdulgani, Roeslan. 2015, The Bandung Connection Konperensi Asia-Afrika di Bandung tahun 1955, Bandung: MKAA-Dirjen Diplik Kemenlu RI, Cetakan keempat.Abdurahman, Dudung. 1999, Metode Penelitian Sejarah, Jakarta: PT. Logos Wacana Ilmu.

Al-Qur'an Cordoba. 2016, Al-Qur'an Cordoba Al-Qur'an Tajwid \& Terjemah (Al-Qur'an Tafsir Bil Hadis), Bandung: Cordoba Internasional Indonesia, Cetakan Ketiga. 
Peran KH. Idham Chalid dalam Konferensi Islam Asia Afrika di Kota Bandung Tahun 1965| Andri Nurjaman dan Asep Sulaiman

Chalid, Idham. 1951, Parlemen, Organisasi dan Tjaranja Bekerdja, Semarang: Astanabuku Abede.

Chalid, Idham. 1965, Islam dan Demokrasi Terpimpin, Jakarta: Api Islam.

Ensiklopedia Islam (1994) dan Apa dan Siapa Sejumlah Orang Indonesia 1985-1986 (1986), tertulis 5 Januari 1922.

Hidajat, S dkk. 1965 Bandung Guide Book, Bandung: The Executive Committee Of The Africa Asia Islamic Conference I.

Kuntowijoyo. 2013, Pengantar Ilmu Sejarah, Yogyakarta: Tirta Wacana.

Mandan, Arief Mudatsir. 2008, Napak Tilas Pengabdian Idham Chalid:

Tanggung Jawab Politik NU Dalam Sejarah, Jakarta: Pustaka Indonesia Satu.

Muhajir, Ahmad. 2007, Idham Chalid Guru Politik Orang NU, Yogyakarta:

Pustaka Pesantren.

Sjamsudin, Helius. 2016, Metodologi Sejarah, Yogyakarta: Ombak, Cetakan Ketiga.

Stoddard, Lothrop. 1963, Dunia Baru Islam, Jakarta: Panitia Penerbit.

Sulasman. 2014, Metode Penelitian Sejarah, Bandung: Pustaka Setia.

\section{Jurnal, Skripsi, Majalah dan Koran}

Atifatur Rohmah. 2019. Dinamika Sejarah Politik NU: Studi Tentang Hubungan NU dan Negara pada Masa Dr. KH Idham Chalid tahun 1956-1984 M. Surabaya: Sejarah Peradaban Islam Fakultas Adab dan Humaniora UIN Sunan Ampel.

Harian Duta Masyarakat, No. 3456, Tahun ke VIII, Jum'at tanggal 17 Februari 1964.

Harian Pikiran Rakyat, No. 222, Tahun ke 15, Rabu tanggal 3 Maret 1965. Harian Pikiran Rakyat, No. 227, Tahun ke 16, Selasa tanggal 9 Maret 1965. Harian Terompet Masyarakat, No, 130, Tahun ke 15, Kamis 11 Maret 1965. Harian Warta Berita, Antara No 59 A, Dalam Negeri, Senin tanggal 1 Maret 1965.

Harian Warta Berita, Antara No 59 B, Dalam Negeri, Senin tanggal 1 Maret 1965.

Harian Warta Berita, Antara No 62 B, Dalam Negeri, Kamis 4 Maret 1965.

Harian Warta Berita, Antara No. 1741, Tahun ke 55, Rabu 3 Maret 1965.

Harian Warta Berita, No, 76 A, KIAA, Jum'at 12 Maret 1965. 
Peran KH. Idham Chalid dalam Konferensi Islam Asia Afrika di Kota Bandung Tahun 1965| Andri Nurjaman dan Asep Sulaiman

M. Mukhsin Jamil. 2000. Jaringan Tarekat dan Dinamika Sosial Politik NU (Studi Hubungan Terekat dan Politik di Indonesia 1957 - 2000). Semarang: Program Pascasarjana IAIN Walisongo.

Majalah: Idham Chalid, Haluan Politik Negara, Majalah Api Islam No. 2 Th. 1- Juli 1965.

Majalah: Idham Chalid, Haluan Politik Negara, Majalah Api Islam No. 3 Th. 1 Juli 1965.

Majalah: Idham Chalid, Haluan Politik Negara, Majalah Api Islam No. 4 Th. 1 Agustus 1965.

Majalah: Idham Chalid, Haluan Politik Negara, Majalah Api Islam No. 5 Th. 1 Agustus 1965.

Majalah: Idham Chalid, Haluan Politik Negara, Majalah Api Islam No. 6 Th. 1 Agustus 1965.

Majalah: Idham Chalid, Haluan Politik Negara, Majalah Api Islam No. 7 Th. 1 Agustus 1965.

Majalah: Idham Chalid, Haluan Politik Negara, Majalah Api Islam No. 9 Th. 1 September 1965.

Majalah: Solichin Salam, KIAA Fadjar Kebangkitan Umat Islam, Majalah Api Islam No. 1 Thn. 1 Juli 1965.

Nur Hidayatullah. 2018. Idham Chalid di Nahdlatul Ulama. Semarang: UIN Walisango Jurnal Idrak Vol, 1 No, 1, Desember 2018.

Pudjiastuti Sudewo, 1989. Konferensi Islam Asia Afrika I, Fakultas Sastra Universitas Indonesia.

Yadi Suryadi. 1984. Peran Indonesia dalam Konperensi Islam Asia Afrika (6-14 Maret 1965). Departemen Pendidikan dan Kebudayaan Universitas Negeri Padjadjaran Fakultas Sastra.

\section{Internet}

Kamus Besar Bahasa Indonesia Online, Diambil dari https://kbbi.web.id/. Diakses pada hari Rabu 08 Januari 2020.

Museum Konferensi Asia-Afrika, Gedung Merdeka dari Masa ke Masa, Diambil dari http://asianafricanmuseum.org. Diakses pada hari Jumat 18 Oktober 2019 pukul 15.38. 